\title{
Pemenuhan Prasarana Jalan dan Drainase Permukiman Kelurahan Tanah Kongkong Kabupaten Bulukumba Provinsi Sulawesi Selatan
}

\author{
Sunandar Syamsuddin ${ }^{1 *}$, Suharman Hamzah ${ }^{1}$, M. Asad Abdurrahman ${ }^{1}$ \\ ${ }^{1}$ Departemen Teknik Sipil, Fakultas Teknik, Universitas Hasanuddin, Makassar \\ Jl. Poros Malino km. 6, Bontomarannu, Kabupaten Gowa, Sulawesi Selatan 92171 \\ *Email: nandarsyam@gmail.com
}

DOI: DOI: 10.25042/jpe.052019.05

\begin{abstract}
Abstrak
Pertumbuhan penduduk di Kelurahan Tanah Kongkong semakin meningkat sehingga kebutuhan akan penyediaan prasarana jalan dan drainase permukiman meningkat pula. Isu tentang prasarana jalan adalah masih ada wilayah yang belum ada jalan, jalan pemukiman sempit dan jalan setapak yang kurang. Tujuan penelitian ini adalah untuk menganalisa dan mengevaluasi pemenuhan prasarana jalan dan drainase permukiman di kelurahan Tanah Kongkong Kabupaten Bulukumba. Penelitian ini menggunakan desain penelitian evaluatif dengan pendekatan kuantitatif-dekriptif. Pengambilan data primer melalui survey, observasi dan kuesioner pada pengguna jalan dan drainase. Data survey diolah dengan menampilkan existing prasarana jalan dan drainase. Data kuesioner diolah dengan metode Importance Performance Indikator (IPA) untuk menampilkan informasi berkaitan dengan faktor-faktor pelayanan yang menurut responden sangat mempengaruhi kepuasan mereka serta faktor-faktor pelayanan yang saat ini belum memuaskan responden sehingga harus ditingkatkan. Sedangkan metode Costumer Satisfaction Index (CSI) digunakan untuk mengetahui tingkat kepuasan pengguna jalan dan drainase secara menyeluruh. Hasil penelitian menunjukkan tingkat kepuasan masyarakat menggunakan metode Costumer Satisfaction Index (CSI) diperoleh nilai CSI sebesar 69\% artinya masyarakat Puas dengan kinerja prasarana jalan. Terhadap evaluasi prasarana drainase persentase jumlah masyarakat yang terlayani drainase adalah sebesar 79,69\% telah melebihi standar minimal, Analisa tingkat kepuasan dengan menggunakan metode Costumer Satisfaction Index (CSI) diperoleh nilai sebesar 61,60\% yang berarti masyarakat Cukup Puas dengan kinerja prasarana drainase. Hasil penelitian menunjukkan bahwa kinerja pelayanan prasarana jalan dan drainase yang ada masih perlu ditingkatkan lagi.
\end{abstract}

\begin{abstract}
Provision of Road Infrastructure and Settlement Drainage in Tanah Kongkong Village, Bulukumba Regency, South Sulawesi Province. The increasing of population growth in Tanah Kongkong sub-district makes the need for the provision on road infrastructure and drainage habitation also increased. Issues on road infrastructure are the limitation of road availability on certain areas, narrow residential roads, and less of pathways. This research is carried out in order to analyze and evaluate the fulfillment of rood infrastructure and drainage habitation at Tanah Kongkong Bulukumba regency. The design of this research is evaluative research with descriptive quantitative approach. The retrieval of primary data on this research employed techniques of survey, observation, and questioner which taken from the road users and drainage. Data which taken from survey is analyzed and presented on existing road infrastructure and drainage mode, meanwhile the data which taken from questioner is analyzed use Importance Performance Indicator (IPA) method in order to explain the information related to service factors which according to respondents, it greatly affect their satisfaction and those factors are not satisfactory at this moment, therefore it should be improved. Another method called Customer Satisfaction Index (CSI) is administered to find out the satisfactory level in overall of the road users and drainage. The results of this research reveal that level community satisfaction which measured using the method of Costumer Satisfaction Index (CSI) obtained CSI value on 69\% means people Satisfie d with the performance of road infrastructure. For evaluation of drainage infrastructure, the percentage of the number of people used drainage is $76.69 \%$ means it has exceed the minimum standard. The satisfaction rate analysis using the Costumer Satisfaction Index (CSI). obtained CSI value on $61.60 \%$ which means people Fairly Satisfied with the performance of drainage infrastructure. This results indicate that the performance of infrastructure on road and drainage services still needs to be improved.
\end{abstract}

Kata Kunci: Drainase pemukiman, evaluasi, kinerja, prasarana jalan 


\section{Pendahuluan}

Pemerintah melalui Undang Undang Republik Indonesia Nomor 1 tahun 2011 tentang Perumahan dan Kawasan Permukiman dalam konsiderannya menyatakan bahwa setiap orang berhak hidup sejahtera lahir dan batin, bertempat tinggal, dan mendapatkan lingkungan hidup yang baik dan sehat, yang merupakan kebutuhan dasar manusia [1]. Dalam Permendagri Nomor 9 tahun 2009 tentang Pedoman Penyerahan Prasarana, Sarana dan Utilitas Perumahan dan Permukiman di Daerah pada pasal 8 disebutkan bahwa prasarana perumahan dan permukiman antara lain adalah Jaringan jalan, dan jaringan saluran pembuangan air hujan (drainase) [2].

Jalan merupakan prasarana transportasi darat yang meliputi bagian jalan termasuk bangunan pelengkap dan perlengkapannya yang diperuntukkan bagi lalu lintas, yang berada pada permukaan tanah, di atas permukaan tanah, di bawah permukaan tanah atau air serta di atas permukaan air [3]. Sedangkan sistem drainase adalah rangkaian bangunan air yang berfungsi untuk mengurangi dan/atau membuang kelebihan air dari suatu kawasan atau lahan, sehingga lahan dapat difungsikan secara optimal yang terdiri dari saluran penerima (interseptor drain), saluran pengumpul (colector drain), saluran pembawa (conveyor drain), saluran induk (main drain) dan badan air penerima (receiving waters) [4].

Keputusan Menteri Permukiman dan Prasarana Wilayah nomor 534/KPTS/M/2001 tentang standar pelayanan minimal bidang penataan ruang, perumahan, permukiman dan pekerjaan umum menetapkan standar pelayanan minimal untuk jaringan jalan Kota sebesar 0,6 km/1.000 penduduk dengan ratio luas jalan 5\% dari luas wilayah, jalan lingkungan sebesar $40-60 \mathrm{~m} / \mathrm{ha}$ dan jalan setapak sebesar 50-110 m/ha [5]. Selanjutnya Peraturan Menteri Pekerjaan Umum Republik Indonesia nomor 01/PRT/M/2014 tentang standar pelayanan minimal bidang pekerjaan umum dan penataan ruang menjelaskan indikator penyediaan jalan untuk melayani kebutuhan masyarakat adalah persentase tingkat kondisi jalan baik dan sedang minimal sebesar $60 \%$. Tingkat kondisi jalan dinilai berdasarkan nilai International Roughness Index
(IRI) yang dapat diperoleh menggunakan metode visual (Road Condition Index/ RCI) [6].

Jumlah penduduk di Kelurahan Tanah Kong Kong tiap tahun semakin meningkat. Seiring dengan itu kebutuhan prasarana permukiman jalan dan prainase meningkat pula. Isu yang berkembang dimasyarakat adalah masih ada wilayah yang belum ada jalan, sebagian jalan pemukiman sempit dan jalan setapak yang masih kurang. Sementara itu banjir pada tanggal 28 Mei 2017 membuat sebagian masyarakat mempertanyakan tentang ketersediaan saluran drainase dan bagaimana pelayanan saluran drainase yang ada. Dengan demikian dibutuhkan suatu analisa terhadap existing prasarana jalan dan drainase serta menganalisa tingkat kepuasan masyarakat sehingga dapat diketahui evaluasi pemenuhan prasarana jalan dan drainase permukiman di Kelurahan Tanah Kongkong kabupaten Bulukumba Provinsi Sulawesi Selatan.

\section{Bahan dan Metode}

\subsection{Lokasi dan Jenis Penelitian}

Penelitian ini dilakukan di wilayah Kelurahan Tanah Kongkong Kabupaten Bulukumba dengan menggunakan desain penelitian evaluatif melalui pendekatan kuantitatif-dekriptif. Jenis penelitian yang digunakan adalah survey dan observasi untuk mengetahui kondisi exsting prasarana jalan dan drainase sedangkan penyebaran kuesioner untuk mengetahui tingkat kepuasan masyarakat terhadap kinerja pelayanan jalan dan drainase.

\subsection{Populasi dan Sampel}

Populasi adalah seluruh kepala keluarga di Kelurahan Tanah Kongkong. Sampel sebanyak 93 orang yang mewakili kepala keluarga terdistribusi di 4 lingkungan yang ada di Kelurahan Tanah Kongkong.

\subsection{Metode Pengumpulan Data}

Pengumpulan data dalam penelitian ini dimulai dengan survey terhadap kondisi existing prasarana jalan dan drainase. Data panjang jalan dan drainase diukur dengan alat pengukur jarak termasuk ukuran jalan dan drainase yang masih baik ataupun 
yang telah rusak sedangkan untuk mengukur nilai RCI jalan dilakukan dengan survey visual terhadap setiap poros jalan yang ada di Kelurahan Tanah Kongkong. Pengumpulan data selanjutnya dilakukan dengan penyebaran kuesioner untuk mengukur tingkat kepuasan terhadap kinerja pelayanan jalan dan drainase.

\subsection{Analisis Data}

Data survey terhadap kondisi existing jalan diolah untuk mendapatkan panjang jalan dan drainase yang ada serta panjang jalan dan drainase yang rusak dan tidak berfungsi, termasuk pengolahan data jumlah rumah dan jiwa yang tidak terlayani sistem drainase. Selanjutnya data Road Condition Index (RCI) hasil survey visual di analisa untuk mendapatkan nilai International Roughness Index (IRI).

Data hasil kuesioner terhadap prasarana jalan dan drainase dilakukan uji validitas dan realibilitas dengan menggunakan SPSS Versi 25 termasuk pengolahan data karakteristik dari sampel. Selanjutnya data di analisa dengan menggunakan metode Importance Performance Analysis (IPA). Analisis ini digunakan untuk membandingkan antara penilaian konsumen terhadap tingkat kepentingan dari kualitas layanan (importance) dengan tingkat kinerja kualitas layanan (performance) [7].

Hasil analisa metode Importance Performance Analysis (IPA) mengelompokkan atribut jalan dan drainase yang prioritas namun berkinerja rendah, atribut yang kinerjanya perlu dipertahankan, atribut yang berkinerja baik namun tidak begitu penting bagi masyarakat dan atribut yang dianggap berlebihan oleh masyarakat. Selanjutnya data diolah lagi dengan metode Costumer Satisfaction Index (SCI) untuk mengetahui tingkat kepuasan masyarakat secara umum terhadap kinerja pelayanan jalan dan drainase.

\section{Hasil}

Tabel 1 memperlihatkan karakteristik responden yang menjadi sampel penelitian ini dimana jumlah responden laki-laki sebanyak 50 orang atau 53,8\% sedangkan perempuan berjumlah 43 orang atau $46,2 \%$. Responden dengan tingkat pendidikan S1 menjadi jumlah responden terbanyak atau sebesar 48,4\%, sementara itu responden sudah bermukim lebih dari 5 tahun di kelurahan Tanah Kongkong sebesar (61,3\%). Responden yang berpenghasilan 1 - 3 juta rupiah sebesar 44,10\% merupakan responden mayoritas.

Tabel 1. Karakteristik responden

\begin{tabular}{ccc}
\hline Jenis Kelamin & Jumlah & Persentase \\
\hline Laki-Laki & 50 & $53,8 \%$ \\
Perempuan & 43 & $46,2 \%$ \\
Total & $\mathbf{9 3}$ & $\mathbf{1 0 0} \%$ \\
\hline Tingkat Pendidikan & Jumlah & Persentase \\
\hline SD & 4 & $4,3 \%$ \\
SMP & 15 & $16,1 \%$ \\
SMA & 24 & $25,8 \%$ \\
S1 & 45 & $48,4 \%$ \\
S2 & 5 & $5,4 \%$ \\
Total & $\mathbf{9 3}$ & $\mathbf{1 0 0} \%$ \\
\hline Tingkat Pendapatan & Jumlah & Persentase \\
\hline < 1 Juta & 30 & $32,30 \%$ \\
1 - 3 Juta & 41 & $44,10 \%$ \\
>3 Juta & 22 & $23,70 \%$ \\
Total & $\mathbf{9 3}$ & $\mathbf{1 0 0} \%$ \\
\hline
\end{tabular}

Tabel 2 memperlihatkan bahwa untuk jalan kota rasio panjang jalan dengan jumlah penduduk adalah $0,88 \mathrm{~km} / 1000$ penduduk. Sementara itu rasio luas jalan berbanding luas kota menghasilkan nilai sebesar 2,69\%, selanjutnya hasil analisa terhadap jalan perumahan/lingkungan terkait rasio panjang jalan dengan luas wilayah mendapatkan rasio 45,78 meter/ha dan untuk jalan setapak rasio panjang jalan dengan luas wilayah mendapatkan hasil sebesar 30,45 meter/ha.

Tabel 2. Capaian existing jalan

\begin{tabular}{|c|c|c|c|}
\hline Indikator & $\begin{array}{r}\text { Standar Kepme } \\
\text { dan Pra } \\
\text { 534/KPTS } /\end{array}$ & $\begin{array}{l}\text { Permukiman } \\
\text { il. No. } \\
\text { 2001 [5] }\end{array}$ & $\begin{array}{c}\text { Capaian } \\
\text { Existing } \\
\text { Jalan }\end{array}$ \\
\hline \multirow{2}{*}{ Jalan Kota } & $\begin{array}{c}\text { Panjang } \\
\text { jalan/Jumlah } \\
\text { Penduduk }\end{array}$ & $\begin{array}{c}0,6 \mathrm{Km} / 1000 \\
\text { Penduduk }\end{array}$ & $\begin{array}{c}0,88 \\
\text { Km/1000 } \\
\text { Penduduk }\end{array}$ \\
\hline & $\begin{array}{c}\text { Luas jalan/Luas } \\
\text { Kota }\end{array}$ & $\begin{array}{c}\text { Luas jalan } \\
5 \% \text { dari Luas } \\
\text { Wilayah } \\
\end{array}$ & $\begin{array}{c}2,69 \% \\
\text { dari Luas } \\
\text { Wilayah } \\
\end{array}$ \\
\hline $\begin{array}{l}\text { Perumahan/ } \\
\text { Lingkungan }\end{array}$ & $\begin{array}{l}\text { Ratio panjang } \\
\text { Jalan dengan } \\
\text { Luas Wilayah }\end{array}$ & $\begin{array}{c}\text { Panjang 40- } \\
60 \mathrm{~m} / \mathrm{Ha} \\
\text { dengan } \\
\text { Lebar } 2-5 \mathrm{~m}\end{array}$ & $\begin{array}{l}45,78 \\
\text { Meter } \\
\text { /Ha }\end{array}$ \\
\hline
\end{tabular}




\begin{tabular}{cccc}
\hline & & Panjang 50- \\
Jalan & Ratio panjang & 110 Meter & 30,45 \\
Setapak & Jalan dengan & /Ha dengan & Meter / \\
& Luas Wilayah & Lebar 0,8-2 & Ha \\
& & Meter & \\
\hline
\end{tabular}

Tabel 3. Panjang jalan yang kondisi baik, sedang dan rusak

\begin{tabular}{cccc}
\hline $\begin{array}{c}\text { Panjang } \\
\text { jalan total } \\
(\mathbf{M})\end{array}$ & $\begin{array}{c}\text { Panjang } \\
\text { jalan } \\
\text { kondisi } \\
\text { baik } \\
(\mathbf{M})\end{array}$ & $\begin{array}{c}\text { Panjang } \\
\text { jalan } \\
\text { kondisi } \\
\text { sedang } \\
(\mathbf{M})\end{array}$ & $\begin{array}{c}\text { Panjang } \\
\text { jalan } \\
\text { kondisi } \\
\text { rusak } \\
(\mathbf{M})\end{array}$ \\
\hline 13.223 & $4.969,2$ & $4.526,9$ & $3.726,6$ \\
\hline
\end{tabular}

Khusus evaluasi kondisi jalan yang dibahas tuntas pada Tabel 3 dengan menggunakan formula dibawah ini didapat hasil sebagai berikut:

$$
\begin{aligned}
\text { SPM Kondisi Jalan } & =\frac{\sum_{\text {achirathumpencapaiansPM }}^{\text {Panjang jalan memenuhi kondisi jalan baik dan sedang }}}{\sum^{\text {eksisiting }} \text { Panjang Jalan }} \\
& =\frac{9.496,1}{13.223,1} \\
& =0.7181 \text { atau } 71,81 \%
\end{aligned}
$$

Pada Tabel 3 memperlihatkan jalan yang dalam kondisi rusak sepanjang 3.726,6 meter.

Tabel 4 memperlihatkan analisa hasil kuesioner dengan metode Importance Performance Analysis (IPA) yang terdistribusi ke dalam 4 kuadran pada kuadran kartesius sebagaimana diperlihatkan pada Gambar 1 menunjukkan bahwa :

a) Pada kuadran $\mathrm{A}$, terdapat atribut prasarana jalan yang belum memuaskan masyarakat dan perlu untuk di prioritaskan peningkatan pelayanannya yaitu :

1) Kondisi drainase jalan yang baik (7)

2) Ada perhatian dari pemerintah untuk perbaikan jalan dan drainase yang rusak (12).

b) Pada kuadran $\mathrm{B}$, terdapat atribut prasarana jalan yang perlu dipertahankan kualitasnya. Atribut tersebut dianggap penting oleh masyarakat dan kinerjanya telah memenuhi harapan masyarakat, yaitu :

1) Tersedianya jaringan jalan untuk berbagai aktivitas (1)

2) Kondisi jalan yang baik dan tidak berlubang (4).

3) Jalan tidak sempit untuk dilalui (5)

4) Sistem penerangan dimalam hari baik (11)

c) Pada kuadran $\mathrm{C}$, terdapat atribut prasarana jalan dengan tingkat kinerja rendah dan dianggap kurang begitu penting, yaitu:

1) Tersedianya jaringan jalan penghubung antar moda darat, laut dan udara (2).

2) Terdapat jalur pejalan kaki (8).

3) Marka dan rambu jalan lengkap sesuai standar (9)

d) Kuadran D, terdapat atribut prasarana jalan dengan tingkat kinerjanya tinggi namun dianggap kurang begitu penting menurut penilaian masyarakat, yaitu :

1) Terdapat drainase di sisi kanan kiri jalan (3)

2) Waktu perjalanan tidak terlalu lama (8).

3) Kondisi jalan yang tidak licin (10).

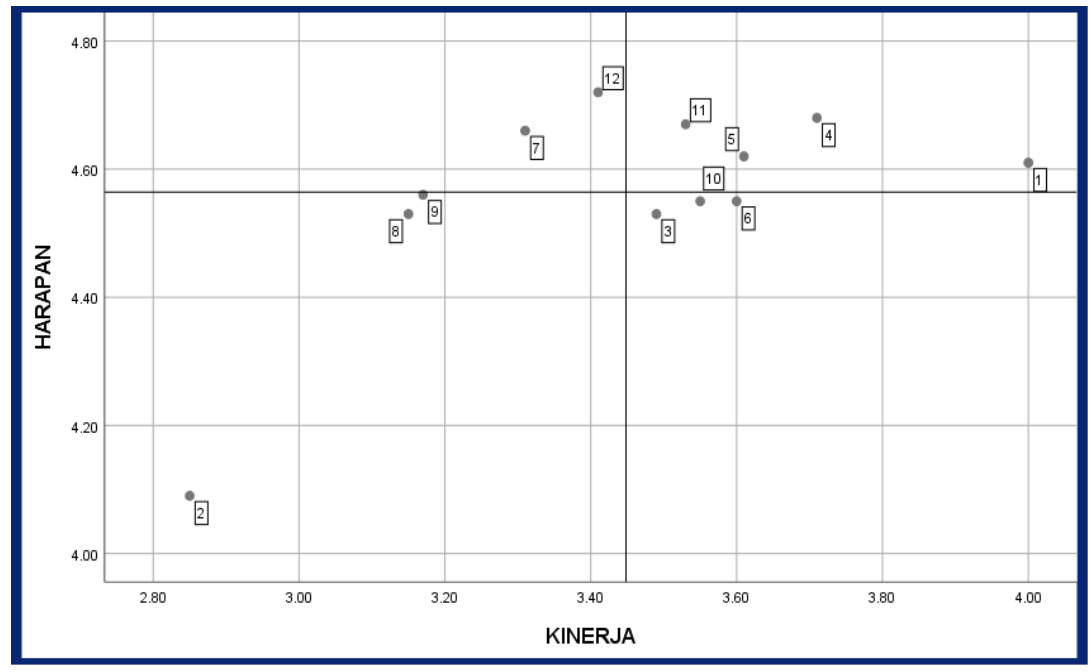

Gambar 1. Diagram kartesius pengkategorian kualitas pelayanan prasarana jalan dengan Importance Performance Analysis (IPA) 
Tabel 4. Analisis tingkat kinerja dan harapan prasarana jalan dengan metode Importance Performance Analysis (IPA)

\begin{tabular}{ccccccccccccc}
\hline \multirow{2}{*}{ Atribut } & \multicolumn{3}{c}{ Aksesibilitas } & \multicolumn{4}{c}{ Kenyamanan } & \multicolumn{6}{c}{ Keselamatan } \\
\cline { 2 - 12 } & $\mathbf{1}$ & $\mathbf{2}$ & $\mathbf{3}$ & $\mathbf{4}$ & $\mathbf{5}$ & $\mathbf{6}$ & $\mathbf{7}$ & $\mathbf{8}$ & $\mathbf{9}$ & $\mathbf{1 0}$ & $\mathbf{1 1}$ & $\mathbf{1 2}$ \\
\hline $\begin{array}{c}\text { Rata-Rata } \\
\text { Tingkat } \\
\text { Kinerja }\end{array}$ & 4,00 & 2,85 & 3,49 & 3,71 & 3,61 & 3,60 & 3,31 & 3,15 & 3,17 & 3,55 & 3,53 & 3,41 \\
$\begin{array}{c}\text { Rata-Rata } \\
\text { Tingkat } \\
\text { Harapan }\end{array}$ & 4,60 & 4,06 & 4,49 & 4,63 & 4,57 & 4,48 & 4,58 & 4,44 & 4,46 & 4,44 & 4,55 & 4,59 \\
\hline
\end{tabular}

Untuk mengetahui besarnya nilai Costumer Satisfaction Index (CSI) hasil perhitungan pada Tabel 5 dimasukkan di dalam formula :

$$
C S I=\frac{\sum_{i=1}^{P} W S i}{H S} \times 100 \%
$$

sehingga mendapatkan nilai sebesar $69 \%$.

Tabel 5. Perhitungan tingkat kepuasan masyarakat terhadap prasarana jalan dengan metode Costumer Satisfaction Index (CSI)

\begin{tabular}{|c|c|c|c|c|c|c|c|}
\hline No. & Indikator dan Atribut & $\sum \mathbf{Y i}$ & $\mathbf{n}$ & $\begin{array}{c}\text { MIS } \\
\text { (Formula 10) }\end{array}$ & MPS & $\begin{array}{c}\text { WF } \\
\text { (Formula } \\
\text { 11) }\end{array}$ & $\begin{array}{c}\text { WS } \\
\text { (Formula } \\
\text { 12) }\end{array}$ \\
\hline $\mathbf{A}$ & Aksesibilitas & & & & & & \\
\hline 1 & Tersedianya jaringan jalan untuk berbagai aktivitas & 428 & 93 & 4,60 & 4 & $8,54 \%$ & 0,34 \\
\hline 2 & $\begin{array}{l}\text { Tersedianya jaringan jalan penghubung antar moda } \\
\text { darat,Laut dan udara }\end{array}$ & 378 & 93 & 4,06 & 2,85 & $7,53 \%$ & 0,21 \\
\hline 3 & Terdapat drainase di sisi kanan kiri jalan & 418 & 93 & 4,49 & 3,49 & $8,33 \%$ & 0,29 \\
\hline B & Kenyamanan & & & & & & \\
\hline 1 & Kondisi jalan yang baik dan tidak berlubang Lubang & 431 & 93 & 4,63 & 3,71 & $8,59 \%$ & 0,32 \\
\hline 2 & Jalan tidak sempit untuk dilalui & 425 & 93 & 4,57 & 3,61 & $8,48 \%$ & 0,31 \\
\hline 3 & Waktu perjalanan tidak terlalu lama & 417 & 93 & 4,48 & 3,6 & $8,31 \%$ & 0,30 \\
\hline 4 & Kondisi drainase jalan yang baik & 426 & 93 & 4,58 & 3,31 & $8,50 \%$ & 0,28 \\
\hline 5 & Terdapat Jalur Pejalan kaki & 413 & 93 & 4,44 & 3,15 & $8,24 \%$ & 0,26 \\
\hline $\mathbf{C}$ & Keselamatan & & & & & & \\
\hline 1 & Marka dan rambu jalan lengkap sesuai standar & 415 & 93 & 4,46 & 3,17 & $8,28 \%$ & 0,26 \\
\hline 2 & Kondisi jalan yang tidak licin & 413 & 93 & 4,44 & 3,55 & $8,24 \%$ & 0,29 \\
\hline 3 & Sistem penerangan dimalam hari baik & 423 & 93 & 4,55 & 3,53 & $8,44 \%$ & 0,30 \\
\hline 4 & $\begin{array}{l}\text { Ada perhatian dari pemerintah untuk perbaikan jalan } \\
\text { dan drainase jalan yang rusak }\end{array}$ & 427 & 93 & 4,59 & 3,41 & $8,52 \%$ & 0,29 \\
\hline & JUMLAH & & & 53,89 & 41,38 & $100 \%$ & 3,46 \\
\hline
\end{tabular}

Tabel 6. Kondisi existing prasarana drainase di kelurahan tanah kongkong

\begin{tabular}{|c|c|c|c|c|c|c|}
\hline \multirow{3}{*}{ No } & \multirow{3}{*}{ Lingkungan } & \multicolumn{5}{|c|}{ Kondisi existing prasarana drainase } \\
\hline & & \multirow{2}{*}{$\begin{array}{c}\text { Panjang } \\
\text { saluran } \\
\text { drainase } \\
\text { (meter) }\end{array}$} & \multicolumn{2}{|c|}{ Saluran drainase yang rusak } & \multicolumn{2}{|c|}{$\begin{array}{c}\text { Saluran drainase yang tidak berfungsi } \\
\text { karena tertimbun seluruhnya }\end{array}$} \\
\hline & & & $\begin{array}{l}\text { Panjang } \\
\text { (M) }\end{array}$ & $\begin{array}{c}\text { Persentase terhadap } \\
\text { panjang total drainase } \\
(\%)\end{array}$ & $\begin{array}{l}\text { Panjang } \\
\text { (M) }\end{array}$ & $\begin{array}{c}\text { Persentase terhadap } \\
\text { panjang total drainase } \\
(\%)\end{array}$ \\
\hline 1 & Tepponge & 2.554 & 120 & 0,68 & 82 & 0,46 \\
\hline 2 & Kasuara Lama & 4.184 & 244 & 1,38 & 289 & 1,63 \\
\hline 3 & Kasuara Baru & 6.984 & 79 & 0,45 & 381 & 2,15 \\
\hline \multirow[t]{2}{*}{4} & Sungai Teko & 3.988 & 95 & 0,54 & 390 & 2,20 \\
\hline & TOTAL & 17.711 & 538 & 3,04 & 1.142 & 6,45 \\
\hline
\end{tabular}


Tabel 6 memperlihatkan panjang saluran drainase di kelurahan Tanah Kongkong sepanjang 17.711 meter yang tersebar di 4 lingkungan. Dari kesulurahan panjang drainase tersebut terdapat drainase yang rusak sepanjang 538 meter atau sebesar 3,04\% dari total panjang saluran drainase, saluran drainase yang tidak berfungsi karena tertimbun tanah yaitu sepanjang 1.142 meter atau sebesar $6,45 \%$ dari total panjang saluran drainase.

Tabel 7. Jumlah penduduk yang belum terlayani saluran drainase di kelurahan tanah kongkong

\begin{tabular}{cccc}
\hline No & Lingkungan & $\begin{array}{c}\text { Jumlah } \\
\text { Penduduk }\end{array}$ & $\begin{array}{c}\text { Jumlah } \\
\text { Penduduk yang } \\
\text { belum terlayani } \\
\text { drainase }\end{array}$ \\
\hline 1 & Tepponge & 603 & 18 \\
2 & Kasuara Lama & 1462 & 567 \\
3 & Kasuara Baru & 1874 & 204 \\
4 & Sungai Teko & 1031 & 220 \\
\hline & T O T A L & $\mathbf{4 . 9 7 0}$ & $\mathbf{1 . 0 0 9}$ \\
\hline
\end{tabular}

Berdasarkan data pada Tabel 7 terdapat 1.009 jiwa yang belum terlayani saluran drainase dari 4.970 jiwa jumlah penduduk di kelurahan Tanah Kongkong atau sebesar 20,30\%.

Untuk mengukur standar pelayanan minimal berdasarkan Permen PU Nomor 01/PRT/M/2014 digunakan formula sebagai berikut :

$S P M=\frac{\text { Jumlah Penduduk yang Terlayani }(A)}{\text { Jumlah Penduduk Seluruh Kota }(B)} \times 100 \%$

Jumlah penduduk yang terlayani $=4.970-$ $1.009=3.961$ jiwa sehingga capaian Standar Pelayanan Minimal drainase existing adalah $79,69 \%$.

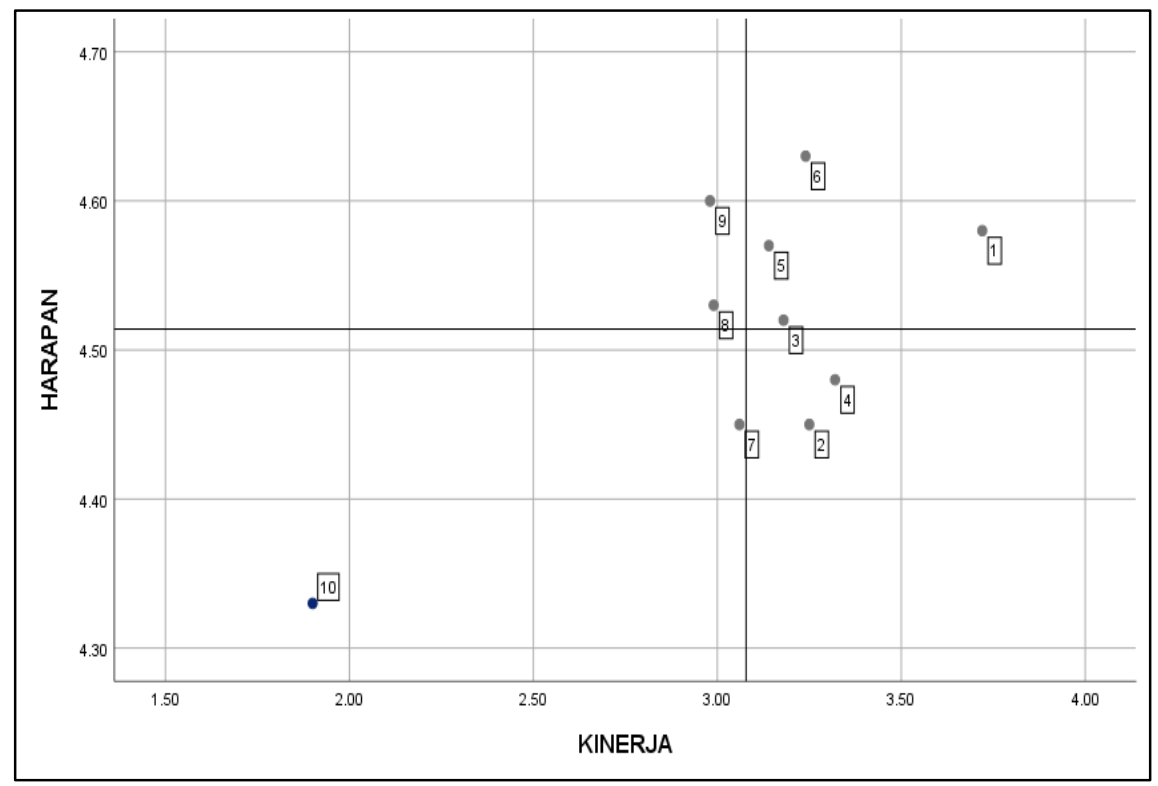

Gambar 2. Diagram kartesius pengkategorian kualitas pelayanan prasarana Drainase dengan Importance Performance Analysis (IPA)

Tabel 8. Analisis tingkat kinerja dan harapan prasarana drainase dengan metode Importance Performance Analysis (IPA)

\begin{tabular}{ccccccccccc}
\hline Atribut & $\mathbf{1}$ & $\mathbf{2}$ & $\mathbf{3}$ & $\mathbf{4}$ & $\mathbf{5}$ & $\mathbf{6}$ & $\mathbf{7}$ & $\mathbf{8}$ & $\mathbf{9}$ & $\mathbf{1 0}$ \\
\hline Rata-Rata Tingkat & 3,72 & 3,25 & 3,18 & 3,32 & 3,14 & 3,24 & 3,06 & 2,99 & 2,98 & 1,90 \\
$\begin{array}{c}\text { Kinerja } \\
\text { Rata-Rata Tingkat } \\
\text { Harapan }\end{array}$ & 4,57 & 4,43 & 4,48 & 4,44 & 4,52 & 4,57 & 4,38 & 4,44 & 4,51 & 4,23 \\
\hline
\end{tabular}


Pada Tabel 8 memperlihatkan analisa hasil kuesioner dengan metode Importance Performance Analysis (IPA) yang terdistribusi ke dalam 4 kuadran didalam kuadran kartesius sebagaiman diperlihatkan pada Gambar 2 menunjukkan bahwa :

a) Kuadran A, terdapat atribut prasarana drainase yang menjadi prioritas utama namun belum memuaskan masyarakat dan perlu untuk di prioritaskan peningkatan pelayanannya yaitu :

1) Saluran drainase selalu di bersihkan secara rutin. (8)

2) Masyarakat terlibat langsung membersihkan Drainase (9).

b) Kuadran B, terdapat atribut prasarana drainase yang perlu dipertahankan kualitasnya. Atribut tersebut dianggap penting oleh masyarakat dan kinerjanya telah memenuhi harapan masyarakat yaitu :

1) Tersedianya jaringan Drainase didaerah permukiman dan jalan (1)

2) Kondisi Saluran Drainase tidak rusak (3).

3) Tidak ada drainase yang meluap (5)
4) Ada perhatian dari pemerintah untuk perbaikan drainase yang rusak (6)

c) Kuadran C, terdapat atribut prasarana drainase dengan tingkat kinerja rendah dan dianggap kurang begitu penting yaitu :

1) Drainase dilengkapi dengan bangunan pelengkap (Gorong-gorong) yang berfungsi dengan baik. (7)

2) Terdapat iuran masyarakat dalam pemeliharaan drainase (10).

d) Kuadran D terdapat atribut prasarana drainase dengan tingkat kinerjanya tinggi namun dianggap kurang begitu penting menurut penilaian masyarakat yaitu :

1) Drainase mengalirkan air dengan lancar (2)

2) Tidak ada genangan air di permukiman setinggi $>30 \mathrm{Cm}$ selama $>2$ jam setelah hujan (2).

Sebagaimana pada perhitungan tingkat kepuasan masyarakat diatas dengan metode Costumer Satisfaction Index (CSI) dengan memperhatikan hasil Tabel 9 didapat nilai kepuasan masyarakat sebesar 61,60\%.

Tabel 9. Perhitungan tingkat kepuasan masyarakat terhadap prasarana drainase dengan metode Costumer Satisfaction Index (CSI)

\begin{tabular}{|c|c|c|c|c|c|c|c|}
\hline No. & Atribut & $\sum \mathbf{Y i}$ & $\mathbf{n}$ & MIS & MPS & WF & WS \\
\hline 1 & $\begin{array}{l}\text { Tersedianya jaringan Drainase didaerah } \\
\text { permukiman dan jalan }\end{array}$ & 426 & 93 & 4,58 & 3,72 & $10,15 \%$ & 0,38 \\
\hline 2 & Drainase mengalirkan air dengan lancar & 414 & 93 & 4,45 & 3,25 & $9,86 \%$ & 0,32 \\
\hline 3 & Kondisi Saluran Drainase tidak rusak & 420 & 93 & 4,52 & 3,18 & $10,01 \%$ & 0,32 \\
\hline 4 & $\begin{array}{l}\text { Tidak ada genangan air di permukiman } \\
\text { setinggi }>30 \mathrm{Cm} \text { selama }>2 \text { jam setelah } \\
\text { hujan }\end{array}$ & 417 & 93 & 4,48 & 3,32 & $9,92 \%$ & 0,33 \\
\hline 5 & Tidak ada drainase yang meluap & 425 & 93 & 4,57 & 3,14 & $10,12 \%$ & 0,32 \\
\hline 6 & $\begin{array}{l}\text { Ada perhatian dari pemerintah untuk } \\
\text { perbaikan drainase yang rusak }\end{array}$ & 431 & 93 & 4,63 & 3,24 & $10,26 \%$ & 0,33 \\
\hline 7 & $\begin{array}{l}\text { Drainase dilengkapi dengan bangunan } \\
\text { pelengkap (Gorong-gorong) yang } \\
\text { berfungsi dengan baik. }\end{array}$ & 414 & 93 & 4,45 & 3,06 & $9,86 \%$ & 0,30 \\
\hline 8 & $\begin{array}{l}\text { Saluran drainase selalu di bersihkan } \\
\text { secara rutin }\end{array}$ & 421 & 93 & 4,53 & 2,99 & $10,04 \%$ & 0,30 \\
\hline 9 & $\begin{array}{l}\text { Masyarakat terlibat } \quad \text { langsung } \\
\text { membersihkan Drainase }\end{array}$ & 428 & 93 & 4,60 & 2,98 & $10,19 \%$ & 0,30 \\
\hline 10 & $\begin{array}{l}\text { Terdapat iuran masyarakat dalam } \\
\text { pemeliharaan drainase }\end{array}$ & 403 & 93 & 4,33 & 1,90 & $9,59 \%$ & 0,18 \\
\hline & Total & & & 45,14 & 30,78 & $100 \%$ & 3,08 \\
\hline
\end{tabular}




\section{Pembahasan}

Berdasarkan Tabel 2 terhadap standar capaian Keputusan Menteri Permukiman dan Praswil No.534/KPTS/M/2001 untuk jalan kota rasio panjang jalan dengan jumlah penduduk didapat $0,88 \mathrm{~km} / 1000$ penduduk menunjukkan bahwa rasio tersebut melebihi standar pelayanan minimal jalan kota yang dipersyaratkan sebesar 0,6 km/1000 penduduk. Sementara itu rasio luas jalan berbanding luas kota dengan standar minimal 5\% tidak terpenuhi dimana rasio yang didapat di kelurahan tanah Kongkong hanya sebesar 2,69\%, sehingga diperlukan penambahan luas jalan di beberapa ruas jalan yang sudah ada. Untuk evaluasi terhadap jalan perumahan/lingkungan terkait rasio panjang jalan dengan luas wilayah memberikan hasil terpenuhi dengan rasio 45,78 meter/ha dimana standar pelayanan minimal adalah 40-60 meter/ha.

Evaluasi untuk jalan setapak terutama rasio panjang jalan dengan luas wilayah mendapatkan hasil sebesar 30,45 meter/ha. Nilai tersebut jauh lebih kecil dari standar pelayanan minimal yaitu sebesar 50 -110 meter/ha. Sehingga untuk jalan setapak di Kelurahan Tanah Kongkong rasionya tidak terpenuhi.

Evaluasi standar pelayanan minimal kondisi existing jalan dengan menggunakan standar yang diterbitkan Permen PU No. 01/PRT/M/2014 sebesar sebesar $60 \%$. Sehingga hasil $71,81 \%$ telah melebihi standar artinya kondisi jalan di Kelurahan Tanah Kongkong telah memenuhi syarat tingkat kondisi jalan minimal.

Hasil analisa Importance Performance Analysis (IPA) menuntut perhatian serius terhadap atribut kondisi drainase jalan yang baik dan ada perhatian dari pemerintah untuk perbaikan jalan dan drainase yang rusak disebabkan kedua atribut ini sangat diprioritaskan oleh masyarakat namun kinerjanya masih belum optimal.

Nilai Costumer Satisfaction Index (CSI) yang didapat sebesar $69 \%$ sesuai Panduan survey kepuasan pelanggan PT.Sucofindo dalam Aditiawarman (2000) masuk kedalam kategori rentang $66 \%-80 \%$ artinya masyarakat puas atas kinerja pelayanan jalan namun nilai tersebut masih jauh dari nilai akhir $80 \%$ dikategori puas sehingga harus ditingkatkan untuk mencapai 0,81 atau $81 \%$.
Sehingga jalan yang dalam kondisi rusak sepanjang 3.726,6 meter sebagaimana pada Tabel 3 dapat diprogramkan untuk dilakukan perbaikan [8].

Hasil pencapaian pelayanan drainase existing sebesar 79,69\% bila di bandingkan dengan standar minimal pada Permen PU Nomor 01/PRT/M/2014 sebesar $50 \%$ maka pelayanan drainase yang ada telah memenuhi standar minimal.

Sementara itu analisa hasil kuesioner dengan metode Importance Performance Analysis (IPA) atribut prasarana drainase yang menjadi prioritas utama peningkatan pelayanannya adalah saluran drainase selalu di bersihkan secara rutin dan masyarakat terlibat langsung membersihkan drainase.

Nilai Costumer Satisfaction Index (CSI) yang didapat sebesar $61,60 \%$ sesuai Panduan survey kepuasan pelanggang PT. Sucofindo dalam Aditiawarman (2000) masuk kedalam kategori rentang $51 \%$ - 65\% artinya masyarakat cukup puas atas kinerja pelayanan drainase namun nilai tersebut masih jauh dari puas sebesar $66 \%$ sehingga harus ditingkatkan untuk mencapai 0,66 atau $66 \% \%$. Sehingga drainase yang dalam kondisi rusak sepanjang 538 meter atau sebesar 3,04\% dari total panjang saluran drainase dan saluran drainase yang tidak berfungsi karena tertimbun tanah yaitu sepanjang 1.142 meter atau sebesar $6,45 \%$ dari total panjang saluran drainase sebagaimana pada Tabel 6 dapat diprogramkan untuk dilakukan perbaikan [8].

\section{Kesimpulan}

Berdasarkan hasil penelitian dapat disimpulkan bahwa secara umum prasarana jalan dan drainase permukiman dikelurahan tanah kongkong sudah memenuhi sebagian besar standar minimal yang telah ditetapkan kecuali rasio luas jalan berbanding luas kota dan rasio panjang jalan dengan luas wilayah yang belum memenuhi standar minimal. Sedangkan untuk tingkat kepuasan masyaraakat terhadap kinerja pelayanan jalan dan drainase sudah puas dan cukup puas. Namun demikian tingkat pemenuhan dan tingkat kepuasan tersebut hanya sedikit diatas standar minimal sehingga Pemerintah Daerah Kabupaten Bulukumba diharapkan membuat sistem 
pengelolaan prasarana jalan dan drainase yang terintegrasi dengan melibatkan multi stekehoulder yang didalamnya ada master plan pengembangan dan pemeliharaan prasarana jalan dan drainase.

\section{Ucapan Terimakasih}

Penelitian ini dilaksanakan di Kelurahan Tanah Kongkong untuk itu diucapkan terimakasih kepada pemerintah Daerah Kabupaten Bulukumba terkhusus Lurah, perangkat kelurahan serta masyarakat. Tak lupa juga diucapkan terimakasih kepada Bapak-bapak komisi penasehat penelitian ini karena dengan bantuan beliau penelitian ini dapat berjalan dengan lancar.

\section{Referensi}

[1] Republik Indonesia, 2011. Undang Undang Republik Indonesia Nomor 1 tahun 2011 tentang Perumahan dan Kawasan Permukiman.
[2] Kementerian Dalam Negeri. 2009. Peraturan Menteri dalam Negeri Nomor 09 Tahun 2009 tentang Pedoman Penyerahan Prasarana, Sarana, Dan Utilitas Perumahan dan Permukiman di Daerah.

[3] Adisasmita, S. A. Transportasi dan Pengembangan Wilayah. Yogyakarta: Graha Ilmu, 2011b.

[4] Grigg, N. Dan Fontane, D. G. 2000, Infrastructure System Management \& Optimazation Internasional Civil Engineering Departement Diponegoro University

[5] Kementerian Pekerjaan Umum. 2001, Peraturan Menteri Pekerjaan Umum Nomor 534/PRT/M/2001 tentang Standar Pelayanan Minimal Bidang Penataan Ruang, Perumahan, Permukiman dan Pekerjaan Umum.

[6] Kementerian Pekerjaan Umum. 2014, Peraturan Menteri Pekerjaan Umum Nomor 01/PRT/M/2014 tentang Standar Pelayanan Minimal Bidang Pekerjaan Umum dan Penataan Ruang.

[7] Tjiptono dan Chandra (2011) Service, Quality and Satisfaction (Ed 3). Yogyakarta. Andi.

[8] Aditiawarman, B.R. 2000. Pengukuran Tingkat Kepuasan Pelayanan (Studi Kasus : Saving And Leading Unit Kopsucopindo). Skripsi Pada Fakultas Matematika dan Ilmu Pengetahuan Alam, Institut Pertanian Bogor, Bogor. 